\title{
Functional characterization of the novel cannabinoid receptor GPR55 and its modulation by $C_{1}$ and $C B_{2}$ receptors
} Nariman Balenga ${ }^{1}$, Julia Kargl ${ }^{1}$, Christopher $\mathrm{M} \mathrm{Henstridge}^{2}$, Andrew J Irving ${ }^{2}$ and Maria Waldhoer*1

\author{
Address: ${ }^{1}$ Institute of Experimental and Clinical Pharmacology, Medical University of Graz, 8010 Graz, Austria and ${ }^{2}$ Centre for Neuroscience, \\ Ninewells Hospital and Medical School, University of Dundee, Dundee, DD1 9SY, UK \\ Email: Maria Waldhoer* - maria.waldhoer@meduni-graz.at \\ * Corresponding author
}

from I4th Scientific Symposium of the Austrian Pharmacological Society (APHAR)

Innsbruck, Austria. 21-22 November 2008

Published: 5 November 2008

BMC Pharmacology 2008, 8(Suppl I):A23 doi:10.1 I86/I47I-22I0-8-SI-A23

This abstract is available from: http://www.biomedcentral.com//47I-22 I0/8/SI/A23

(c) 2008 Balenga et al; licensee BioMed Central Ltd.

We have recently shown that the G protein-coupled receptor 55 (GPR55) mediates intracellular effects of cannabinoids and other, non-cannabionid, ligands in addition to the classical cannabinoid $1\left(\mathrm{CB}_{1} \mathrm{R}\right)$ and $2\left(\mathrm{CB}_{2} \mathrm{R}\right)$ receptors. Here we show that the presence of either $\mathrm{CB}_{1} \mathrm{R}$ or $\mathrm{CB}_{2} \mathrm{R}$ alters the signaling pathways of GPR55. HEK-293 cells stably expressing either the GPR55 receptor alone or in combination with either $\mathrm{CB}_{1}\left(\mathrm{CB}_{1} / \mathrm{GPR} 55\right)$ or $\mathrm{CB}_{2}$ $\left(\mathrm{CB}_{2} / \mathrm{GPR} 55\right)$ receptors were characterized in terms of signaling and receptor trafficking properties. To this end, FLEX calcium release, reporter gene and antibody feeding assays have been performed. Here we show that GPR55 is activated by lysophosphatidylinositol (LPI) and couples to Ga13, which in turn activates RhoA and RhoA kinase (ROCK). Moreover, we discovered that GPR55 activation leads to an efficient activation and nuclear translocation of nuclear factor of activated T-cells (NFAT) transcription factor family. We next tested a panel of known cannabinoid ligands and discovered that GPR55 is activated by AM251, which is a known inverse agonist on the $\mathrm{CB}_{1} \mathrm{R}$. In addition, the $\mathrm{CB}_{1} \mathrm{R}$ antagonist SR141716A (rimonabant) was able to induce GPR55-mediated signaling, although it was less potent than both AM251 and LPI. LPI was also able to induce the internalization of GPR55. Lastly, we found that $\mathrm{CB}_{1} \mathrm{R}$ and $\mathrm{CB}_{2} \mathrm{R}$ co-localize with GPR55 on the surface of HEK cells and also can block the NFAT activation mediated by GPR55. 